\title{
Nordic Noir: Branding Nordicness as British Boreal Nostalgia
}

In the first decades of the twenty-first century, Nordic crime fiction has become a local and a global obsession, constituting a sub-genre of crime fiction in its own right. ${ }^{1}$ With a stock of glum detectives, cold, desolate landscapes and a penchant for social critique, crime novels and television series from the Nordic countries form a recognisable international brand, which is used in the marketing and export of not only the crime stories themselves, but also consumer goods, tourist destinations, Nordic lifestyles, and social values.

This chapter explores how the reading and consumption of Nordic crime fiction in the 2010s, particularly in the UK, became enmeshed in a much wider and pervasive rhetoric of Nordicness made recognisable under the brand name of Nordic noir. I am going to argue that when Nordic crime fiction travels abroad, it is consumed as a globalised cultural good, desirable for its blend of transnational generic forms and its exotic local anchoring. A utopian Nordicness or borealism - a term to be discussed later in this chapter - may best describe the allure of what is associated with Nordic noir in its British reception. Here, all things Nordic have come to represent an imagined, desirable topography ${ }^{2}$ bestowed with stereotypical Nordic traits, sampling everything from social values to well-designed consumer products, which can be accessed en bloc through the consumption of crime fiction.

One suggestive example of how Nordic crime fiction has been used in the branding of non-Nordic consumer products is a British television commercial used in a marketing campaign for the petrol company Esso. The company's creative agency produced a commercial in the style of a Scandinavian crime drama, complete with a minimalist, gloomy set and actors speaking in Danish with English subtitles. ${ }^{3}$ In the commercial, a witness, who turns out to be an Esso engi-

1 See Kerstin Bergman, Swedish Crime Fiction: The Making of Nordic Noir (Milan: Mimesis, 2014), 173; Barry Forshaw, Death in a Cold Climate: A Guide to Scandinavian Crime Fiction (Houndmills: Palgrave Macmillan, 2012); and Jakob Stougaard-Nielsen, Scandinavian Crime Fiction (London: Bloomsbury, 2017).

2 I am using the term "topography" (literally, "place writing”) to designate the confluence of real, physical places and their complex and changing discursive, affective, or rhetorical figurations. See J. Hillis Miller, Topographies (Stanford: Stanford University Press, 1995), 3-4.

3 Esso, “Esso - Fuel Engineer,” 1 September, 2017, YouTube video, 1:00, https://youtu.be/ g9caGx-RkTc. In the UK, subtitled foreign television programmes were a rarity, until the screen- 
neer with a remarkable eye for detail, helps the Danish detectives solve a case with Scandinavian-style meticulousness. It is implied that "Esso is renowned for having meticulous attention to detail in everything it does - including developing fuel formulations that are designed on a molecular level to help improve engine performance." ${ }^{4}$ The connection between Nordic noir and a new fuel system is far-fetched, to say the least. Why did Esso choose to use Danish television drama as a vehicle for its branding, especially since there is no shortage of homegrown television drama or British detectives obsessed with forensic detail? The commercial suggests not only how iconic subtitled Nordic crime drama has become in the UK over the past decade; more importantly, it points to an implicit set of images that have become popularly associated with a contemporary rhetoric of Nordicness. ${ }^{5}$

The Esso commercial was meant to reach a segment of British middle-class consumers, readers, and television viewers, which, I argue, is no longer looking for confirmation of their own identities and social aspirations exclusively within the Anglophone sphere. To these viewers the affective engagement with Nordicness has become synonymous with wider aspirational cosmopolitan desires. However, the cosmopolitan consumption of Nordic noir and a concomitant desire for Nordicness is a complex phenomenon to locate, as it is stimulated partly by Nordic self-presentations and a receiving culture's analogous use of the Nordic to express its own local desires and concerns. While Esso could have drawn from a locally sourced list of perfectionist detectives, the Nordicness of subtitled quality television drama allows the advertiser to target an audience who wants to participate in current, legitimate consumer behaviour. The Nordic noir brand-

ing of Nordic television dramas on BBC FOUR from 2009 onwards. The experience of reading subtitles on the screen became a marker for the fascination with - and exotic foreignness of - Nordic noir drama series (see Jakob Stougaard-Nielsen, "Nordic Noir in the UK: The Allure of Accessible Difference," Journal of Aesthetics \& Culture 8, no. 1 (January 2016): 32704, doi:10.3402/jac.v8.32704.

4 John Wood, "New Synergy Supreme + Unleaded launched," Forecourt Trader Online, 1 September, 2017, https://forecourttrader.co.uk/news/new-synergy-supreme-unleaded-launched/ 640519.article.

5 In a UK context, it is significant that even though the original language spoken by the actors in the commercial is Danish, the associated cultural background, as understood by viewers, is of a general Nordic character. Furthermore, the choice of the term "images" in this paragraph is informed, as my analyses and argument in this chapter generally, by the theory of image studies or imagology, associated with the work of Joep Leerssen. See, for instance, Joep Leerssen, "Here follows A summary of imagological theory," Imagologica: Dedicated to the critical study of national stoeretypes, n.d., para 6, accessed 1 May, 2021, https://imagologica.eu/theoreticalsummary. 
ing also allows the company to draw on a set of positive values associated with the Nordic region (e.g. that it is egalitarian, socially just, functionalist, rational, healthy, and harmonious), which have become re-actualised and re-articulated through the popularisation of Nordic crime fiction, the "mystery" of Nordic happiness, NOMA's locally foraged Nordic food and the Danish hygge-craze. ${ }^{6}$

In the following, I shall discuss how the publishing, marketing, and reception of Nordic crime fiction in the UK, along with television documentaries and a recent deluge of articles and popular books on life, hygge, and happiness in the Nordic countries, present the region neatly packaged to the extent that all recognisable elements - history, art, culture, food, and consumer trends - appear mutually dependent, causal and, importantly, essentially local or regional. Viewed through contemporary popular cultural discourses in the UK, Nordic social realities are portrayed as attractive and authentic destinations that provide what might have been lost at home, but also as destinations that have already been prepared for a "tourist gaze."7 As such, this chapter will argue that the rhetoric of Nordicness, around the international success of Nordic crime fiction at home and abroad, poses both a challenge and an opportunity for re-assessing what the rhetoric of Nordicness may signify in the twenty-first century.

\section{From Nordic Crime Fiction to Nordic Noir}

The story about the international success of Nordic crime fiction is by now well known. ${ }^{8}$ The details of the genre's success in the Anglophone world, leading to the widespread adoption of the term Nordic noir, are worthwhile summarising nevertheless as they demonstrate the genre's unique impact and formation within a complex contemporary media situation, in a changing commercial and transnational field.

6 See Lily Kelting's chapter in this volume.

7 John Urry, The Tourist Gaze: Leisure and Travel in Contemporary Societies (London: Sage Publications, 1990).

8 Susan Bassnett, "Detective Fiction in Translation: Shifting Patterns of Reception," in Crime Fiction as World Literature, ed. Louise Nilsson, David Damrosch, and Theo D'haen (London: Bloomsbury, 2017), 149; Barry Forshaw, Nordic Noir: The Pocket Essential Guide to Scandinavian Crime Fiction, Film and TV (Harpenden: Pocket Essentials, 2013); Wendy Lesser, Scandinavian Noir: In Pursuit of a Mystery (New York: Farrar, Straus and Giroux, 2020); Andrew Nestingen and Paula Arvas, "Introduction: Contemporary Scandinavian Crime Fiction," in Scandinavian Crime Fiction, ed. Andrew Nestingen and Paula Arvas (Cardiff: University of Wales Press, 2011); Stougaard-Nielsen, Scandinavian; and Steven Peacock, Swedish Crime Fiction: Novel, Film, Television (Manchester: Manchester University Press, 2014). 
It started with the global publishing phenomenon of Stieg Larsson's Millennium trilogy. ${ }^{9}$ In Sweden, the trilogy was well received and praised for its blending of social indignation with a thrilling plot. Originally published by Sweden's oldest independent publishing house, Norstedts, the Trilogy's international rise to fame was initiated when published in French by the independent publisher Actes Sud. When subsequently published in English in 2008 by yet another independent publisher, Quercus, it was, against all odds, set on its way to becoming "the biggest publishing phenomenon of the 21st century," according to British journalist and author Mark Lawson. ${ }^{10}$ Indeed, as David Geherin reminds us, Larsson's The Girl Who Played with Fire became "the first translated novel in 25 years to top the coveted New York Times best seller list."11 While the Anglophone publishing markets have been notoriously impenetrable to foreign language fiction, ${ }^{12}$ several Nordic crime series have subsequently been translated into English and dozens more languages, and authors such as the Swedes Arne Dahl, Camilla Läckberg and Liza Marklund, the Norwegian Jo Nesbø and the Dane Jussi Adler-Olsen have sold millions of copies of their crime novels outside of the Nordic region. ${ }^{13}$

The success of Scandinavian crime fiction, particularly in the UK, has given birth to expressions such as "Scandimania," "the Nordic invasion," and "the Swedish crime fiction miracle," 14 a rhetoric suggesting how rare it is for literatures from smaller language areas to make an impact on the UK and US markets. ${ }^{15}$ Curiously, while the Nordic countries have generally been perceived as small, peripheral, or semi-peripheral nations on the northern fringe of the European cultural and linguistic centres, the Nordic countries punch well above their

9 Larsson, Stieg, The Girl with the Dragon Tattoo (2005; New York: Alfred A. Knopf, 2008); Larsson, Stieg, The Girl Who Played with Fire (2006; New York: Alfred A. Knopf, 2009); Larsson, Stieg, The Girl Who Kicked the Hornets' Nest (2007; New York: Alfred A. Knopf, 2009).

10 Mark Lawson, "Crime’s grand tour: European detective fiction," The Guardian, 26 October, 2012, https://www.theguardian.com/books/2012/oct/26/crimes-grand-tour-european-detectivefiction.

11 David Geherin, The Dragon Tattoo and its Long Tale: The New Wave of European Crime Fiction in America (London: McFarland, 2012), Kindle.

12 See Rajendra Chitnis et al., eds., Translating the Literatures of Small European Languages (Liverpool: Liverpool University Press, 2020).

13 See Nestingen and Arvas, "Introduction," and Forshaw, Death.

14 Johan Svedjedal, "Svensk skönlitteratur i världsperspektiv,” in Läsarnas Marknad, marknadens läsare: En forskningsantologi utarbetad för Literaturutredningen, ed. Ulla Carlsson and Jenny Johannisson (Göteborg: Nordicom, 2012), 209.

15 See Chitnis, Translating. 
weight when it comes to international publishing. Monitoring the language spread of bestsellers on several European markets between 2008 and 2014, Miha Kovač and Rüdiger Wischenbart have found that the impact of Nordic authors on translations and sales is striking, establishing a cohort very similar to authors writing in English:

\begin{abstract}
The readers' rush for Nordic crime is the tip of a giant iceberg that has grown over several decades ... After Stieg Larsson's success, a new dynamics led to an explosion of translations, with new incoming authors to include Liza Marklund, Camilla Läckberg, Jens Lapidus, Lars Kepler, Jo Nesbø, Arnaldur Inðridason, Yrsa Sigurðardóttir and many others. Their reach was further broadened by international acclaim for Scandinavian TV series of the same genre, such as The Killing, The Bridge, The Protectors, Unit One and Mamon. ${ }^{16}$
\end{abstract}

Significantly, Kovač and Wischenbart suggest that the international publishing success of Nordic crime fiction is closely tied to regional (Nordic) synergies and cross-mediality: the success of Larsson's novels (adapted for both a Swedish and an English-language film); the success of authors from across the Nordic region and the coincident successes of Swedish television adaptations; and original Danish television drama followed by serials from the rest of the region. In fact, in 2008, the same year that Larsson's first instalment of the Millennium trilogy was published in English translation, the UK public broadcaster BBC witnessed the first signs of a dramatic shift in the popularity of subtitled foreign television drama, beginning with the Swedish series based on Henning Mankell's Wallander novels. This subtitled series aired on the niche channel BBC FOUR alongside BBC's own English language adaptation of the Wallander novels, filmed in and around Ystad with British actors including Kenneth Branagh. The British adaptation aired on the main channel BBC ONE to great acclaim and with a much larger audience - 5-6 million viewers - than the 150,000 who regularly viewed the original Swedish adaptation - a reach that still constituted a relative success for BBC FOUR. ${ }^{17}$

Subtitled foreign drama had been a rarity in the UK, and literary translations have consistently represented an insignificant share of the total publishing mar-

16 Miha Kovač and Rüdiger Wischenbart, "Diversity Report 2016: Trends and references in literary translations across Europe," Verein für kulturelle transfers, accessed 13 September 2018, www.culturaltransfers.org, 27.

17 Andrea Esser, "Form, Platform and the Formation of Transnational Audiences: A Case Study of How Danish TV Drama Series Captured Television Viewers in the United Kingdom," Critical Studies in Television: The International Journal of Television Studies 12, no. 4 (December 2017): 419-20, doi:10.1177/1749602017729649. 
ket, lingering at around 4 percent. ${ }^{18}$ The BBC's subsequent venture into purchasing the rights to the twenty-episode Danish original crime series Forbrydelsen (2007-12; The Killing 2011-12) became a game changer, and it was followed by several successful Nordic productions and co-productions such as Borgen (2010-13; UK 2012-13) and Broen/Bron (2011-2018; The Bridge 2012-18). ${ }^{19}$ While outperforming previous attempts to screen subtitled television series, these Nordic series still reached a relatively small share of around one million viewers. However, Forbrydelsen made Nordic series a "cult hit" in the British press, it fuelled the burgeoning consumption of "box sets" - Forbrydelsen sold 300,000 units in the UK - and helped consolidate the brand BBC FOUR as a platform "offering an ambitious range of innovative, high quality output that is intellectually and culturally enriching."20 Judging by sales and viewer numbers, Larsson's Millennium trilogy and BBC's Wallander had much wider public appeal. However, the relative niche phenomenon of original Nordic television drama imbued the genre with a status only afforded high-end consumer products, prestigious cultural experiences, and the rise of what has been called "complex TV."21

The international success of Scandinavian crime fiction and television drama around 2008 - 9 was to some extent accidental. The trajectory of Larsson's Millennium Trilogy from a national and regional bestseller to a global phenomenon three years after its original publication was made possible by smaller independent publishers abroad. The simultaneous English language adaptation of Mankell's Wallander series by the BBC, and the attempt by BBC to reinvigorate their niche channel through the Swedish Wallander series, led to the acquisition of the Danish drama series Forbrydelsen, which was inexpensive at the time. While popular and well received in Denmark, the success of Forbrydelsen as a cultural trendsetter in a central, international television market such as the UK's was unpredictable and unprecedented..$^{22}$ However, together these Scandina-

18 See Chitnis, Translating.

19 See Linda Badley, Andrew Nestingen, and Jaakko Seppälä, eds., Nordic Noir, Adaptation, Appropriation (Cham: Palgrave, 2020), and Esser, "Form."

20 Esser, "Form," 418. See Jakob Stougaard-Nielsen, "Revisiting the Crime Scene: Intermedial Translation, Adaptation, and Novelization of The Killing," in Nordic Noir, Adaptation, Appropriation, ed. Linda Badley, Andrew Nestingen, and Jaakko Seppälä (Cham: Palgrave, 2020).

21 Jason Mittell, Complex TV: The Poetics of Contemporary Television Storytelling (New York: New York University Press, 2015).

22 According to Pia Majbritt Jensen, after Forbrydelsen, Danish audio-visual drama series experienced an "unprecedented global boom in exports." Pia Majbritt Jensen, "Global Impact of Danish Drama Series: A Peripheral, Non-commercial Creative Counter-flow,” Kosmorama 263 (2016), https://www.kosmorama.org/en/kosmorama/artikler/global-impact-danish-drama-series-pe- 
vian "accidents" drew attention from publishers, broadcasters, media, and critics who began to look for common denominators - a secret Nordic formula behind the success of their crime dramas - and the next Stieg Larsson.

The earliest instances of the use of the term "Nordic noir," which became the reference for this formula, may have been in a Wall Street Journal article in early 2010 and by the Nordic Noir Crime Fiction Book Club established by the Department of Scandinavian Studies at University College London, which started its activities in the Spring of the same year. ${ }^{23}$ Subsequent "agents" that propelled the consolidation of the term in the public imagination and contributed to the growth of its symbolic capital, at least in the UK, include: the BBC documentary Nordic Noir: The Story of Scandinavian Crime Fiction (December 2010); reviews and blogs hosted by The Guardian; the distributor of television drama and films Arrow Films, who adopted the brand name Nordic Noir for their Scandinavian TV dramas and established the Nordicana festival in London in 2013; and Barry Forshaw's survey of the genre in his book Death in a Cold Climate (2012). ${ }^{24}$

Moreover, actors such as publishers and media corporations within the Nordic region soon capitalised on and helped promote the brand of national and Nordic crime fiction. Karl Berglund has convincingly demonstrated, for instance, that particularly the rise of literary agents in Sweden, who rely heavily on the sale of translation rights, coincided with and helped propel the international

ripheral-non-commercial-creative-counter. On the transnational dissemination and remaking of Nordic television drama, see Badley, Nordic Noir; Pei-Sze Chow, Anne Marit Waade, and Robert A. Saunders, "Geopolitical Television Drama Within and Beyond the Nordic Region," Nordicom Review 41, no. s1 (1 September 2020): 11-27, doi:10.2478/nor-2020 - 0013; and Stougaard-Nielsen, Revisiting.

23 Ove Solum, "What is it about Nordic Noir?," in Perspectives on the Nordic, ed. Jakob Lothe and Bente Larsen (Oslo: Novus Press, 2016), 115-18; Gunhild Agger, "Nordic Noir - Location, Identity and Emotion," in Emotions in Contemporary TV Series, ed. Alberto N. García (Houndmills: Palgrave, 2016), 138.

24 For the sake of full disclosure, it should be mentioned that I was the founder of the Nordic Noir Book Club. See "The History of the 'original' Nordic Noir Book Club in London," Nordic Noir Book Club, accessed 8 September 2021, https://scancrime.wordpress.com/events. I was also interviewed for the BBC documentary and Forshaw's Death in a Cold Climate, and wrote a short history of Scandinavian crime fiction for Arrow Films, which they used as an inlay for box sets. My colleagues and I, in the UCL Department of Scandinavian Studies, have frequently been interviewed for articles in The Guardian and have collaborated with the newspaper on creating additional content for their coverage of Nordic television drama and cultures. This exemplifies the extent to which invested agents have been centrally involved in the promotion and, not least, contextualisation of Nordic noir in the UK. 
success of Swedish crime writers in the 2000s. ${ }^{25}$ Therefore, the rise of what has become known as the transnational Nordic noir brand came to exemplify what Claire Squires has called a "cultural shift" in publishing, towards a marketingled publishing culture with its "growing professionalization and businessbased practice of publishing." ${ }^{26}$ Following this cultural shift, the circulation of literature and other media started to take place in more fluid, mutually fertilising, and open networks driven by commercial interests and audience expectations and desires.

The somewhat coincidental cross-media success of Nordic crime fiction together with its wider matrix of related brands, demonstrates, as argued elsewhere, that "literature does not travel solo and nor does it travel light; it is carried and accompanied by films, television series, translators, publishers, state subsidies, and all manner of lifestyle goods." 27 This prompts us to consider Nordic noir a complex, ever evolving transnational brand. As suggested in a handbook entry on "Nordic Noir," the concept is "associated with a region (Scandinavia), with a mood (gloomy and bleak), with a look (dark and grim), and with strong characters and a compelling narrative." 28 However, "confusingly" it is also "associated with disparate, bleak dramas set in particular locations outside the Nordic region ... such as Wales, Italy, France, Mexico, and the United States."29

As a brand, Nordic noir has become thoroughly mobile, loosening its ties to “actual” Nordic topographies, writers, languages, and cultures. The British television drama Fortitude (written by Simon Donald, 2015) is an example of how late Nordic noir has transformed the "Nordic" from its "authentic" locations into a set of loose references to previous series (the leading role is played by Sofie Gråbøl known from Forbrydelsen), Nordic names and words in an otherwise Anglophone and multicultural location ("Politi" on the crest of police uniforms) and geographical references to the Arctic and the Northern lights. This continuing internationalisation of Nordic crime fiction points to the fact that it

25 Karl Berglund, "With a Global Market in Mind: Agents, Authors, and the Dissemination of Contemporary Swedish Crime Fiction," in Crime Fiction as World Literature, ed. Louise Nilsson, David Damrosch, and Theo D'haen (London: Bloomsbury, 2017).

26 Claire Squires, Marketing Literature: The Making of Contemporary Writing in Britain (Houndmills: Palgrave, 2009), 35.

27 C. Claire Thomson and Jakob Stougaard-Nielsen, "A faithful, attentive, tireless following: Cultural Mobility, Crime Fiction and Television Drama," in Danish Literature as World Literature, ed. Dan Ringgaard and Mads Rosendahl Thomsen (London: Bloomsbury, 2017), 237.

28 Annette Hill and Susan Turnbull, "Nordic Noir," Oxford Research Encyclopedia of Criminology, 26 April, 2017, doi.org/10.1093/acrefore/9780190264079.013.294.

29 Hill and Turnbull, "Nordic Noir," para. 1. 
only became a recognisable genre or brand as novels and television series became widely translated, subtitled, and adapted into foreign languages and markets. ${ }^{30}$ Nordic crime fiction is only really "Nordic" when viewed or read from abroad - when published, marketed, and sold in bookshops, book fairs or at broadcasting trade fairs, where the branding of national or regional peculiarities is essential for attracting the attention of potential funders, publishers, agents, and book buyers in a crowded, globalised field. ${ }^{31}$

As a popular and bestselling genre, crime fiction has always operated in the more commercialised end of the publishing spectrum. In their introduction to the anthology, Perspectives on the Nordic, Jakob Lothe and Bente Larsen write that a productive "reciprocity" between various perspectives on the Nordic across genres and media is "often marginalized and suspended by the noise of the culture industry that in the name of commercialism turns 'the Nordic' into a cliché, thus making it into a kind of commercial brand." ${ }^{32}$ According to the authors, Nordic noir is "one of the most important elements of the commercial branding of the Nordic region." 33 It is also a cliché "prompted by a number of Nordic television series that became hugely popular in many countries."34

We need to consider whether it is possible to identify perspectives on the Nordic across genres and media without accounting for the "noise of the culture industry" and its attendant commercialism. As a commercial brand, Nordic noir tends to smooth over the local and national particularities of the region - differences that seem particularly important to the peoples living within the Nordic region. Kim Toft Hansen and Anne Marit Waade are aware of this tension between the somewhat empty brand value of the term and the potentially productive, "reciprocal," access it offers to the "use value" of Nordic locations: "Basically, 'Nordic Noir' sounds slightly more sexy and appealing than 'Scandinavian crime fiction,' or the abbreviated 'Scandi-crime'. It is infused with brand value." 35 However, since "Nordic Noir refers to the place of origin

30 Though the novelty of Nordic crime fiction on international markets has worn off, Nordic crime novels continue to be translated in disproportionate numbers considering the size of the home markets. Writers outside of the Nordic region continue to write "Nordic Noir" crime novels set in the Nordic region, and Nordic television series continue to find viewers abroad and are adapted and appropriated for early-2020s foreign markets.

31 Jakob Stougaard-Nielsen, "Nordic noir in the UK."

32 Jakob Lothe and Bente Larsen, ed. Perspectives on the Nordic (Oslo: Novus Press, 2016), 10.

33 Lothe and Larsen, Perspectives, 19.

34 Lothe and Larsen, Perspectives, 11.

35 Kim Toft Hansen and Anne Marit Waade, Locating Nordic Noir: From Beck to The Bridge (London: Palgrave, 2017), 8. 
or the narrative diegetic space" it is also congruent with "crime fiction as a world brand," which makes it "hardly surprising that narratives taking place locally are used locally to brand places. Altogether, places, themes, and characters are closely tied in crime fiction - and this clearly applies to Nordic Noir as well." ${ }^{36}$

Their approach in Locating Nordic Noir is not to ask what Nordic noir is, as one would have done in a traditional genre study, but instead to inquire "Where is Nordic Noir?" They thereby emphasise, on the one hand, the centrality of authentic topographies and "local colour" in the narratives themselves, ${ }^{37}$ and on the other, how real and imagined locations are shaped in the reciprocal branding and consumption across invested interest groups, agents, and nations. Examples of place branding are particularly evident in television drama where local and regional interest groups, such as municipalities and local film funds, find an opportunity to put their location "on the map" by promoting and enabling access to relevant locations. Subsequently, such "fictionalised" actual locations can be used by tourism agencies as desirable destinations. The well-known case of Ystad's promotion of "Wallanderland" is one notable early example of Nordic noir place branding. ${ }^{38}$

While the specific Nordic locations together with their national languages may appear to erode with the profusely transnational brand of Nordic noir, several studies have argued for the centrality of the genre's perceived Nordicness. In his detailed genealogy of the term in the international press, Ove Solum argues that "crime fiction has become the most important area for cultural export and the unprecedented international appeal of Nordic Noir, in tandem with a growing international interest in what in short can be described as Scandinavianness, has been utilized to promote the 'Nordic' and Nordic culture." ${ }^{39}$ With reference to the London-based Nordicana fair mentioned earlier, which co-promoted Nordic-noir television drama by inviting Nordic actors, and showcasing Nordic travel destinations and food items, Solum points out that popular genres have become instrumental in the branding of the Nordic region by foregrounding both actual and imagined "Nordic" places and locations. Such place-branding used by an external actor to sell television box sets has in turn prompted the tourism industry in the Nordic countries to embrace the phenomenon for its own purposes. "Nordic Noir," Solum concludes, "is not only expanding as a

36 Toft Hansen and Waade, Locating, 9.

37 Toft Hansen and Waade, Locating, 10.

38 See Anne Marit Waade, Wallanderland: Medieturisme og Skandinavisk TV-krimi (Aalborg: Aalborg Universitetsforlag, 2013).

39 Solum, "What is it," 122. 
genre beyond the Nordic countries; it has also become a phenomenon that far exceeds the group of texts that constitutes the genre."40

It is, in other words, impossible to understand the rise of Nordic noir without considering the wider commercial interests and agents involved in and gaining from the making and branding of the phenomenon: from writers, publishers, literary agents, translators, and production companies to television distributors, media outlets, educational, cultural, and tourism institutions both in and outside the Nordic region. What is, perhaps, most salient about the Nordic noir brand from a UK perspective is the fact that the vast range of literary and audio-visual texts it subsumes, located variously within and beyond the Nordic region, are made to participate in a rhetoric of Nordicness that attaches certain persistent values to images and discursive constructions of the "North."

\section{Branding Borealism}

Louise Nilsson has noted the importance of accounting for the marketing and media discourses in reception countries to understanding the success and impact of Nordic noir. She suggests that "[i]n the case of Nordic Noir, ... the marketing and media discourse visually merged a local literature with crime fiction's global discursive field and its mediascape by successfully connecting to a cosmopolitan imaginary of the north." ${ }^{41}$ Reviewers in Anglophone newspapers, according to Nilsson, construct a discursive image of the Nordic region through repeated use of figures such as coldness, ice, and morose detectives. This rhetoric of Nordicness has been used profusely in the marketing of Nordic noir abroad (as demonstrated by Agnes Broomé's study of "Nordic" book-cover designs), and Nilsson suggests that the foreign appeal of Nordic noir may partly rest "on a longstanding culturally forged idea of the north." 42

A suggestive term for such a deeply rooted rhetoric of Nordicness at the heart of the recent "Scandimania" in the UK is "borealism." ${ }^{33}$ Sylvain Briens's invalu-

40 Solum, "What is it," 123.

41 Louise Nilsson, "Mediating the North in Crime Fiction," Journal of World Literature 1, no. 4 (2016): 542, doi:10.1163/24056480-00104007.

42 Agnes Broomé, "Swedish literature on the British market 1998-2013: A systemic approach" (PhD diss., University College London, 2014); Nilsson, "Mediating”, 546.

43 Sylvain Briens, "Boréalisme: Pour un atlas sensible du Nord," Études Germaniques 2 (2018): 151-76; Kristinn Schram, "Banking on Borealism: Eating, Smelling, and Performing the North," in Iceland and Images of the North, ed. Sumarliði Ísleifsson, in collaboration with Daniel Chartier (Québec: Presses de l’Université du Québec, 2011). 
able discussion of the term corresponds to a "reciprocal perspective" on the Nordic or the North and brings out the significance of topography and the reciprocal rhetoric of Nordicness, which I see as central to the phenomenon of Nordic noir. Briens argues that borealism involves an external view that perceives the North as a homogeneous whole and foregrounds topographical and climatic aspects that are also central to the Nordic noir brand. The etymological root of the word, "Boreas," refers to the Ancient Greek God of the North wind, and has cultural roots in a "North-South schematization of temperamental oppositions" the North as cool, frugal, cerebral, morally inclined and the South as warm, sensual, opulent and immoral. According to Joep Leerssen, this has been "one of the more long-standing matrices imposed on the imaginary of Europe's cultural landscape": "In the European imagination, the image of Scandinavia and the Nordic countries has been deeply influenced by this master-polarity. Climate is associatively correlated with landscape, with human habitation patterns, with social and political organization, and in turn rationalized by reference to the inhabitants' purported 'character.'”45

As a brand, Nordic noir is deeply enmeshed in a borealist discourse, a term around which we find a congregation of multi-directional desires and affective responses. Nordic crime fiction became an "accidental” trigger for a new borealism in the UK fuelled by various sources: the coincidental international success of Stieg Larsson and Nordic television drama produced by an increasingly internationalised, commercialised, and intermedial market for cultural products; and the global infatuation with the Nordic welfare state as an (utopian) model for creating just, egalitarian, and, not least, happy societies in the wake of the global financial crisis (2007-8). Nordic noir came into being as a product of these converging generic, affective, topographical, medial, and boreal perspectives or rhetorics. In the following section of this chapter, examples from the media, television documentaries, nation branding, popular ethnography, and lifestyle journalism will be discussed as exemplifying the borealist and multidirectional perspectives on the Nordic that have followed the "Scandimania" initiated by the success of Nordic noir in the UK.

44 Joep Leerssen, "Forword.” in Images of the North: Histories, Identities, Ideas, ed. Sverrir Jakobsson (Amsterdam: Rodopi, 2009), 16.

45 Leerssen, "Forword," 16. 


\section{Inspector Norse}

One of the first examples of journalistic treatments of the Nordic crime phenomenon in the Anglophone world, the 2010 article "Inspector Norse" published in The Economist, captures in its title a key fascination with the Nordic as both recognisable and somewhat exotic, and, importantly, conforming to deeply rooted figurations of the Nordic. The title refers to the British crime television series Inspector Morse. ${ }^{46}$ By replacing Morse with Norse, it references an external homogeneous understanding of the inherent Nordicness of the new crime wave, while recalling a deep-seated cultural memory and British stereotype of invading (Norse) Vikings.

The article presents a more current image of the Nordic countries as orderly, crime free, and with enviable well-functioning welfare states that seem to contradict the image presented in crime novels: "The neat streets of Oslo are not a natural setting for crime fiction." This paradox leads to the question: why have Nordic detective novels become so successful? Some shared characteristics are emphasised. Apart from the always gloomy, melancholic detectives, the article points to a particular Nordic style of crime writing characterised by simple and plain writing devoid of metaphor. This attractive style of crime writing is complemented with the lure of the Nordic setting, which links imagined landscapes of the "cold, desolate north" with a dystopian view of the fate of the Nordic welfare societies: "The countries that the Nordic detectives call home are prosperous and organised ... But the protection offered by a cradle-to-grave welfare system hides a dark underside." ${ }^{47}$

This figure of a Nordic "dark side" would become central to the image of Nordic noir, and it was repeated in another early article on the phenomenon, Ian MacDougall's review of Stieg Larsson's trilogy “The Man Who Blew Up the Welfare State." While Swedish crime fiction, according to MacDougall, "owes its greatest debt to its British forebear, whose plots it cheerfully rips off ... the Swedish model distinguishes itself by infusing these plots with a social and political consciousness." ${ }^{48}$ He summarises Larsson's main themes as "the failure of the welfare state to do right by its people and the failure of men to do right by women" - a theme that was more obviously foregrounded in the Swedish title of

46 Inspector Morse, ITV, 1987-2000.

47 “Inspector Norse: Why Are Nordic Detective Novels So Successful?” The Economist, 11 March, 2010, accessed 1 May, 2021, http://www.economist.com/node/15660846.

48 Ian MacDougall, "The Man Who Blew Up the Welfare State," $n+1$ Magazine, 27 February, 2010, https://nplusonemag.com/online-only/book-review/man-who-blew-up-welfare-state. 
the first novel in the Trilogy, Män som hatar kvinnor, which translates as Men Who Hate Women. The novels' critical depiction of the welfare state's "well-polished façade" and "welfare-state comforts", hiding widespread moral and political corruption, exemplify a now widely accepted view of Nordic crime fiction as depicting "the comprehensive failure of the world's most comprehensive welfare system”, as it is poignantly formulated by MacDougall.

Larsson's deceptively realist and socio-critical style (devoid of metaphor), MacDougall suggests, allows us to imagine (from abroad) that all is not right in Sweden, an orderly, rather boring place hiding a dark underbelly. Of course, the setting of violent crime stories involving misogynist Nazi serial killers and a corrupt police state in locations commonly perceived to be peaceful, democratic, egalitarian and just is an enticing premise - one that perhaps counter-intuitively highlights a Nordic exceptionalism instead of succeeding in "blowing it up". However, to some readers like MacDougall the realism effects of Nordic crime writing present a stark critique of the utopian socialist paradise in the North, much in the same way the British journalist Roland Huntford's notorious The New Totalitarians (1971) critiqued the moral and psychological demise of the social-democratic welfare state. ${ }^{49}$

Perhaps in a dual effort to exploit the global popularity of Larsson's Swedish crime novels for nation-branding purposes and to counteract the possible misconception that Larsson was necessarily drawing an accurate picture of Sweden, the Swedish Institute (SI) produced the report Sweden beyond the Millennium and Stieg Larsson. ${ }^{50}$ The Institute, which has since the 1940s worked to produce and promote a Swedish national image abroad ${ }^{51}$ - explains that they had noticed, when reviewers abroad wrote about Larsson's Millennium trilogy, they often went into greater details about Sweden as well: "The Millennium trilogy is in some ways a dramatization of 21st century Swedish society." 52 The report, therefore, tries to understand this "new" perspective on Sweden offered by the books and attempts to respond to and participate in the branding of Sweden, including the significance of the welfare state.

That nation branding and tourism are central aspects of the report is evident from its abundant illustrations of Swedish locations, landscape images, and

49 Roland Huntford, The New Totalitarians (London: Allen Lane, 1971).

50 The Swedish Institute, Sweden beyond the Millennium and Stieg Larsson (Stockholm: Swedish Institute, 2012), https://issuu.com/swedish_institute/docs/sweden_beyond_the_millennium. 51 Nikolas Glover, "Imaging Community: Sweden in "Cultural Propaganda" Then and Now," Scandinavian Journal of History 34, no. 3 (23 September 2009): 246-63, doi:10.1080/ 03468750903134707.

52 The Swedish Institute, Sweden beyond the Millennium, 34. 
even the northern lights, some of which have little relevance for the books themselves. Through its report, the SI participates self-consciously in a jostling for control over the image of Sweden "beyond the Millennium," since "it is a known fact that cultural expressions such as film and literature can have an effect on people's impression of a place, for example a country." 53

The SI walks a fine line between accepting the brand value of Larsson's bleak view of the modern Swedish welfare state - arguing that Larsson's portrait of Sweden makes the country appear less utopian and less dull ("the notion of Sweden as a conflict-free model nation is shattered"), which has been great for tourism - and attempting to control the brand by explaining that the Sweden of the books is not what you would find if you visited from abroad. ${ }^{54}$ SI reminds us that the books also portray a modern, industrious nation with proud democratic traditions, where, for instance, a journalist has the right to speak out against the state. Through suggestive illustrations, Sweden is promoted as a country rich in majestic, markedly Nordic landscapes and a well-functioning state.

Apart from demonstrating the to-and-fro branding of Nordicness taking place between internal and external agents, the branding of Sweden through crime fiction - in consort with a host of other cases where local tourism boards use famous crime stories to brand their cities, towns, and regions across Scandinavia - risks participating in the maintenance of an un-reflexive boreal branding and the construction of essentialist national or regional identities, what David Pitcher has called, "a corporate model of Nordic ethnicity." According to his study of consumer practices and ethnicity in the contemporary UK:

The repeated connection between landscape and aesthetics produces a highly consistent portrait of a Nordic temperament. Psychological dispositions and ethical, social and spiritual values are shown to be the simultaneous product of a place and the ideas and practices it generates. This corporate model of Nordic ethnicity is, I want to suggest, precisely what has given Nordic style such a strong purchase in a contemporary British context..$^{55}$

Importantly, this "corporate model" is not exclusively produced by internal agents such as tourism boards or by the crime stories themselves but become "incorporated" in the transnational exchange of boreal imagery and Nordic imaginings with markets, consumers, reviewers, readers, and viewers outside of the Nordic region. ${ }^{56}$

53 The Swedish Institute, Sweden beyond the Millennium, 5.

54 The Swedish Institute, Sweden beyond the Millennium, 34-5.

55 David Pitcher, Consuming Race (London: Routledge, 2014), 66.

56 See the similar case and argument in Kelting's chapter on "New Nordic Cuisine" in the present volume. 


\section{Cracking the Norse Code: From Boreal Utopianism to Scandimania}

As implied in the reviews and report discussed above there is a particularly striking, some might say troubling, element to the contemporary British fascination with Nordic culture - an infatuation, Pitcher identifies as, "a romanticized reading of the politics of Nordic social liberalism and social democracy as produced out of the same 'natural' combination of climate, geography and culture." 57 Nowhere is this eighteenth-century climate theory and borealist perspective on the Nordic more explicitly and self-consciously stated than in Andrew Graham-Dixon's three-part BBC documentary Art of Scandinavia. ${ }^{58}$

In his introduction to the series, it becomes clear that a running theme throughout the series will be an exploration of what the national and regional art of Scandinavia may tell us about the "Scandinavian mind" and how it has been shaped by its "northern" locations and landscapes. While it is clear that the presenter is well aware that a "climate theory" of national or regional belonging has been discredited and proven dangerous fodder for ethno-essentialist ideologies, it is similarly clear that his encounter with the Nordic landscape per excellence - the sublime Norwegian fjords - leaves him unable to understand Nordic art, culture, and societies as anything but the products of their topographies. He finds himself perpetually in an "exotic" North where the "forbidding beauty" of the landscapes and their "remoteness" from an unspecified cultural centre - the South, likely London - impress themselves as self-evidently "so far north" that the landscapes themselves must present the key to unlocking the Scandinavian mind:

Scandinavia. The Nordic lands. So far north, they've often been simply left off the map of world civilisations. Art, literature, philosophy - these belonged to the lands of the south. Of sunshine, warmth, the light of reason. To the north lay the shadow lands, the lands of perpetual midnight and darkness. But that's not the whole story.... The art of Scandinavia reflects their stormy history, played out in landscapes of forbidding beauty. Nature's been the great enemy, but it's also been the great inspiration. Not just for painting and poetry, but for architecture and design. Inspired by the frozen forms of ice, or dark forests of pine. You could say the Scandinavian mind itself has been shaped by nature, like a landscape formed by a glacier. Despite their remoteness, the Nordic peoples have managed to fashion one of

57 Pitcher, Consuming.

58 Art of Scandinavia, presented by Andrew Graham-Dixon, BBC 4, 2016, 4,https:// www.bbc.co.uk/programmes/b0745j6 m. 
the most remarkable civilisations. And the art of Scandinavia shares many of the characteristics of the Scandinavian landscape - hardness, sharpness, clarity. I think the north has also given it some of its most distinctive moral and psychological characteristics. Pride tempered by a sense of living at the margins - anxiety, loneliness, melancholy. And blowing through it all, like a cold, piercing wind, an absolute determination to endure, come what may. ${ }^{59}$

This "rhetoric of Nordicness" makes generous use of borealist imagery (coldness, ice, dark, frozen, glaciers, remoteness). Graham-Dixon links the features of an imagined, homogeneous, and perpetual climate with unchanging and distinctive "moral and psychological characteristics" of the Scandinavian nations and the region (Norden). Nordicness, therefore, begins with landscapes and a climate that have inevitably been impressed on the Nordic peoples. Their art reveals national and regional, moral and psychological characteristics, and leads us to understand why it is the Nordic countries have become "remarkable civilizations" the much admired, successful welfare societies of the twentieth and twenty-first centuries.

Guided by representatives of the Nordic noir craze such as the Danish actor Søren Malling, famous in Britain as Jan Meyer from the first season of Forbrydelsen, and the Swedish crime-writing team behind the pseudonym Lars Kepler, Graham-Dixon goes in search for Danish "happiness" and the "underbelly of the Modern Swedish welfare state." Although persuaded that "Nordic noir dredges up ugly truth" ${ }^{61}$ about the Swedish welfare state, and being told to take the train out of Stockholm to the suburbs if he wants to experience the shadows of the welfare state in situ, he:

can't find the Badlands described by the social critics of modern Sweden. Nothing truly Noir, for sure. In fact, if I had to name a city that exemplifies failing social services, a crumbling transport infrastructure and yawning chasms of wealth, I'd pick London any day over Stockholm. And on even the most remote station, the Swedish underground still does really beautiful benches. ${ }^{62}$

Art of Scandinavia begins with the nations' topographies, their national-romantic, anxious landscape paintings and ends with a perception of the art of Scandinavia as always, in one way or the other, engaged in national self-presenta-

59 Art of Scandinavia, episode 1, "Dark Night of the Soul," directed by Ian Leese, presented by Andrew Graham-Dixon, aired 14 March, 2016, on BBC 4, https://www.bbc.co.uk/programmes/ b073mp87.

60 Art of Scandinavia, episode 1, "Dark Night of the Soul."

61 Art of Scandinavia, episode 1, "Dark Night of the Soul."

62 Art of Scandinavia, episode 1, "Dark Night of the Soul." 
tions, as borne out of a "Scandinavian mind" and how this mind eventually shaped the Nordic model of welfare. This perception illustrates the curse of small nationhood: cultural expressions are reduced to homogeneous national characteristics in comparison with the cultural centre - while local diversity, temporal discontinuities, contradictions or cosmopolitan traits are unacknowledged.

It is, of course, easy to dismiss such causal simplifications regarding topography, art, and identity. While the documentary does suggest a notable cosmopolitan British interest in the Nordic countries, it is an interest less preoccupied with understanding the foreign not merely as different but also diverse and potentially cosmopolitan. However, the rhetoric of Nordicness may ultimately have not much to do with the Nordic region itself. One could view Graham-Dixon's borealism as less interested in Scandinavian art and its local uses and more preoccupied with how these Nordic national arts can be used to critically assess current social conditions and national discourses in Britain. It is not a simple British nostalgic longing for a utopian welfare society, the Nordic region is imagined as a grouping of "authentic" and "rooted" societies that have been able to respond critically and creatively to the social transformations brought on by neoliberalism and globalisation. This rhetoric of Nordicness in the UK, I would argue, represents an internal British attempt to come to terms with the nation's own inability to present a unified, "corporate ethnic," national narrative. Such a narrative would stretch from the landscapes of Turner and Wordsworth to a harmonious, homogeneous, and thoroughly content twenty-first century nation, without having to consider contemporary British dislocations, the disharmonies of historical imperialism, social inequalities, and the ravages of a thoroughly neoliberal welfare state.

British borealism is a complex multi-focal "ethnography of looking at the North" where images and narratives produced in and of the Nordic allow for the sharing of certain "affective topographies" - "the kind of affect that binds people to places or that imbues a place with desire." ${ }^{63}$ In the contemporary use of the "Nordic" in the UK, these are commonly linked to perceptions of what makes a good society. The Nordic does not represent a distant, exotic, topographic other employed to bolster a sense of British superiority. On the contrary, Nordicness represents a utopian ideal of a more "tidy," "cleaner and neater" Britain. An example of this was expressed in a piece of tongue-in-cheek travel journalism recounting a tour of Scandinavia in 2018:

63 Lila Ellen Gray, Fado Resounding: Affective Politics and Urban Life (Durham and London: Duke University Press, 2013), 137. 
The British relationship with Scandinavia is not complex. We are in awe. They are bettergoverned, better-dressed, better-looking and write better crime novels. Of course, we can always claim a bit of shared ancestry. Many of the quiet Danish villages I had passed through on the train to Hirtshals had names that would fit seamlessly into the Lincolnshire or Yorkshire Wolds. In fact this rolling rural landscape dotted with woodland is not dissimilar, though cleaner and neater. As I'd gazed out that train window, I'd wondered: what if the Vikings had persisted a little longer with their civilising ventures into Britain, would London have the unhurried cool of Copenhagen, could Essex be tidy, and might there be no need for Luton at all?”64

This alternative boreal British past realised in a tidy, ordered contemporary Scandinavia suggests a widespread, but also paradoxical type of nostalgia: a borealist nostalgia expressed in a longing for the north as a home that was never realised; a transnational nostalgia for the simplicity of a time now long gone both in the Nordic region and in the UK. Such a "welfare nostalgia” for a culturally appropriated Nordic past was perhaps best exhibited in the set design for the BBC Wallander series. The home of Wallander and the police station in Ystad were consciously styled in the fashion of 1950s Scandinavian design, using functionalist welfare aesthetics to give them the air of a coolly rational, socially engineered society - which Mankell described as disintegrating in Wallander's Sweden of the early 1990s.

According to the production designer, she "wanted to symbolize the Swedish utopia of the 1950s and 1960s by choosing Scandinavian interior design and architecture from this period." 65 Some Nordic scholars have noted the exotification of Sweden or the "banal nationalism" presented in the British Wallander adaptation. Ingrid Stigsdotter remarks that "the ubiquity of classic wooden desks, lampshades and decorative furnishing ... stand out as being at once a little too stylish and a little too old-fashioned to be quite real."66 In her view, this translation or adaptation sees Sweden predominantly through a touristic lens. However, the nostalgic Swedish utopia encoded in the location and the set of

64 Kevin Rushby, "King of Denmark: How to Create Hygge in a Cabin by the Sea,” The Guardian, 5 August, 2018, https://www.theguardian.com/travel/2018/aug/05/denmark-beach-seaside-scandinavia-holiday-cabin.

65 Quoted in Anne Marit Waade, "Crime Scenes: Conceptualizing Ystad as Location in the Swedish and the British Wallander TV Crime Series," Northern Lights: Film \& Media Studies Yearbook 9, no. 1 (28 July 2011): 20, doi:10.1386/nl.9.9_1.

66 Ingrid Stigsdotter, "Crime Scene Skåne: Guilty Landscapes and Cracks in the Functionalist Façade in Sidetracked, Firewall and One Step Behind," in Regional Aesthetics: Locating Swedish Media, ed. Erik Hedling, Olof Hedling, and Mats Jönsson (Stockholm: Mediehistoriskt Arkiv, 2010), 254. 
the Wallander series may also point to the way in which nostalgic borealism functions as a significant affective topography in contemporary Britain.

Therefore, this particular example of converging national and transnational nostalgia demonstrates an important point raised by Toft Hansen and Waade concerning what they call "Norientalism": "Norientalism may thus be both an image held by the reader of Nordic fiction, but there is also a good chance that the international spatial image, whether brightly romantic or melancholically ambivalent, is motivated by the self-image portrayed in written fiction." ${ }^{67}$ Just as Nordic crime fiction can be seen to exhibit nostalgia for the utopian ideals of a bygone golden age of the welfare state (as in Mankell's Wallander novels), so the infatuation with the Nordic in the UK may be understood as a transnational nostalgia for a place and a time that never belonged to the British - an affective topography exhibiting a borealist nostalgic longing for the north as a home that never was. ${ }^{68}$

This would also partly explain why the Nordic noir craze has petered out into an obsession with Nordic lifestyles, wellness, and popular Nordic buzzwords such as Swedish lagom, Danish hygge, and Norwegian friluftsliv. A deluge of lifestyle television programmes and books have appeared in the UK portraying the Nordic countries individually and together as mostly utopian societies, as a desirable yet unattainable nostalgic "elsewhere." A pertinent example is Hugh Fearnley-Whittingstall's food, travel, and lifestyle series Scandimania. ${ }^{69}$ (Channel 4, 2014). His tour of Scandinavia presents a veritable "nation-crush", a "scandimania" for Nordic wellness, institutionalised egalitarianism, a dedication to sustainability, a strong sense of community and quality of life. Fearnley-Whittingstall's narrated introduction is a further example of the converging interests in "all things Nordic" where landscape, food, society and crime fiction make up a seemingly un-breakable or untranslatable "Norse code", which he will, nevertheless, attempt to "crack" to reveal why these nations, and not Britain, are among the happiest in the world:

There's a lot of talk about Scandinavia at the moment. Their food is setting the gastronomic world on fire. Nordic noir dramas have us glued to our screens. And Sweden, Norway and Denmark are officially three of the happiest countries in the world. I want to find out why. ls it their connection to nature and their breath-taking landscapes? Their spirit of coopera-

67 Toft Hansen and Waade, Locating, 111.

68 See Stougaard-Nielsen, Scandinavian, 115-21.

69 Scandimania, presented by Hugh Fearnley-Whittingstall, aired 2014, on Channel 4, https:// distribution.channel4.com/programme/scandimania. 
tion? And does the famed dark side of Scandinavia really exist? To crack the Norse code, l'm about to immerse myself in Scandimania. ${ }^{70}$

The potential for branding consumer goods, arising from this popularised boreal view of the Nordic region as seen from the UK, was not lost on Carlsberg, which in 2017 started a marketing campaign, which included a television commercial that aired on Channel 4 in the UK with the slogan "brewed in the UK the Danish way." 71 The commercial is rendered in nostalgic autumnal colours and light and features the internationally renowned Danish actor Mads Mikkelsen riding an old-fashioned bicycle through Copenhagen's cobbled streets, past national landmarks and a "hyggelig" forest picnic, finally to arrive at the Carlsberg brewery. Throughout the commercial, Mikkelsen philosophises about the secret to Danish happiness: "Could it be that we find joy in nature? Could it be that we keep life and work in perfect balance? Is it that we make time for hygge, feeling all fuzzy and snuggly together?"72

The commercial suggests that British consumers now have the opportunity to follow "the Danish way" by drinking the rebranded Carlsberg Export, a brand of beer brewed in the UK and commonly associated with low-brow consumption and poor quality. The commercial taps into the British import of "hygge" - a craze which erupted in 2016 with more than a handful of books published in the UK on the phenomenon, most notably Meik Wiking's The Little Book of Hygge. ${ }^{73}$ Wiking's hygge book, which sold more copies than most Nordic crime novels in the UK, is clearly written for a general British audience, as he attempts to explain how "hygge" makes the Danes happy through references to statistics, his own experiences, and "shared" Danish values and traditions. In his presentation of Danish lifestyles and customs, "hygge" conforms to a borealist matrix of values such as simplicity, modesty, casualness, and familiarity. Anti-consumerism, being in nature, playing board games instead of watching television and surrounding oneself with hand-crafted rustic furnishings is "hyggeligt" and,

70 Scandimania, episode 1, "Sweden," presented by Hugh Fearnley-Whittingstall, aired 2 February, 2014, on Channel 4, https://distribution.channel4.com/programme/scandimania.

71 See Ellen Kythor, "Stereotypes in and of Scandinavia," in Introduction to Nordic Cultures, ed. Annika Lindskog and Jakob Stougaard-Nielsen (London: UCL Press, 2020), 219-20.

72 See Carlsberg, "Carlsberg - The Danish Way 60", 26 April, 2017, YouTube video, 1:00, https://www.youtube.com/watch?v=1v8n7lL-frA\&ab_channel=CarlsbergUK.

73 See Alison Flood, "Hygge - the Danish art of living cosily - on its way to UK bookshops," The Guardian, 11 June, 2016, https://www.theguardian.com/books/2016/jun/11/hygge-the-danish-art-of-living-cosily-on-its-way-to-uk-bookshops. 
he realises towards the end, "hygge" is essentially nostalgic: "I was tripping on nostalgia."74

\section{Conclusion}

The few cases I have selected - out of a plethora of similar ones - demonstrate the assertion previously quoted by the Swedish Institute that "cultural expressions such as film and literature can [indeed] have an effect on people's impression of a place." However, the origin and effect of the Nordic noir brand within and outside of the Nordic region is by no means monodirectional. In a transnational, cross-medial, and commercialised culture industry, the circulation of national and regional images, stereotypes, and values is thoroughly fluid and dialogic, constantly responding to and sharing affective topographies, which reflect deep-seated historical matrices of geographical polarities.

Genres - and crime fiction in particular - have the power "to shape topographies of affect," to bind people to certain places that hold deep historical and rhetorical values, and reflect current desires for lost opportunities. ${ }^{75}$ A transnational genre such as Nordic noir suggests that such desirable places and public feelings need not coincide with one's own location. A segment of British readers, viewers, and consumers has been remarkably receptive to the Nordic noir brand, to the dark nostalgic tales of a "lost welfare paradise," and to stories about losing what once was firmly rooted - and Nordic content providers and agents have responded in kind by preparing and elaborating on the Nordic brand for an external gaze and consumer. Out of this sharing of narratives, self-presentations, and external imaginings, a new rhetoric of Nordicness has evolved that I suggest we name borealist nostalgia - a reciprocal longing for a North that was never one's own.

74 Meik Wiking, The Little Book of Hygge (London: Penguin, 2016), 281. 75 Gray, Fado, 137. 